\title{
A New Species of Nannoscincus Günther (Squamata: Scincidae) from High Elevation Forest in Southern New Caledonia
}

\author{
Ross A. SAdlier ${ }^{1 *}$, Aaron M. BAUER ${ }^{2}$, And SARAH A. SMith ${ }^{2}$ \\ ${ }^{1}$ Australian Museum, 6 College Street, Sydney NSW 2010, Australia \\ rosss@austmus.gov.au \\ ${ }^{2}$ Department of Biology, Villanova University, \\ 800 Lancaster Avenue, Villanova, Pennsylvania 19085, United States of America \\ aaron.bauer@villanova.edu ·sarah.a.smith@villanova.edu
}

\begin{abstract}
A new species of Nannoscincus from relictual high elevation closed forest is described from southern New Caledonia. This species is most similar in appearance to Nannoscincus gracilis, but can be distinguished by its large size and a suite of distinctive scalation characters. Further, it is the only species of Nannoscincus recorded as being able to vocalise. The species is known only from closed forest patches on Pic Ningua and adjacent Mt Çidoa at around $1000 \mathrm{~m}$ in altitude. The overall extent of this habitat is small, fragmented, and in an area that is actively mined. As such the species is regarded as at risk, and the level of threat as Vulnerable.

Une nouvelle espèce de Nannoscincus provenant d'une forêt relique fermée d'altitude est décrite du sud de la Nouvelle-Calédonie. Cette espèce est d'apparence similaire à Nannoscincus gracilis, mais peut s'en différencier par sa grande taille et une série de caractères d'écaillure distinctifs. De plus, c'est la seule espèce de Nannoscincus capable de vocaliser. Cette espèce n'est connue que des lambeaux de forêt fermée du Pic Ningua et du Mt Çidoa voisin, à environ $1000 \mathrm{~m}$ d'altitude. La répartition actuelle de ce type d'habitat est limitée, fragmentée, et localisée dans une zone fortement soumise à l'impact minier. Pour toutes ces raisons, cette espèce est considérée comme sensible et placée à un niveau de menace «vulnérable».
\end{abstract}

SAdlier, Ross A., AARON M. BAuer \& SARAH A. Smith, 2006. A new species of Nannoscincus Günther (Squamata: Scincidae) from high elevation forest in southern New Caledonia. Records of the Australian Museum 58(1): 29-36.

Recent studies on the endemic lizard fauna of New Caledonia have revealed the presence of species endemic to high elevation forests on various peaks along the length of the island. In the central and northeast ranges two species appear to be found only at elevations greater than $900 \mathrm{~m}$, the diminutive scincid Nannoscincus rankini from Mont Aoupinié (Sadlier et al., 2002), and the gecko Bavayia

* author for correspondence madjo from Mont Panié and Mont Ignambi in the Panié Range (Bauer et al., 2000). The forest at both Mont Aoupinié and the Panié Range is more or less continuously distributed from mid elevation $(400 \mathrm{~m})$ to the summits.

By contrast, high elevation forest on the ultramafic peaks in the south and northwest of the island generally are present as isolated patches, separated from lowland forest by 
extensive areas of maquis shrubland, which covers much of the mid and lower elevation slopes of these massifs. Our knowledge of the lizard fauna of forests on the peaks of the southern ultramafic massifs is heavily biased by accessibility. Mont Ouin and Mont Mou in the region of Dumbéa are part of a network of interconnected ranges with peaks over $1000 \mathrm{~m}$ elevation. Field research on these mountains has revealed a particularly rich endemic lizard fauna in high elevation forests, including two species of scincid lizard, Sigaloseps ruficauda and Marmorosphax montana (Sadlier \& Bauer, 1999, 2000), and an undescribed gecko (Bavayia) restricted to this habitat.

Further to the north isolated patches of high elevation forest occur on the various ultramafic peaks from the Massif du Humboldt north and west to Mont Do, however, most of these are relatively inaccessible and the composition of their lizard faunas is in most instances unknown. Collections made on the ultramafic peaks of Pic Ningua and nearby Mont Çidoa (formerly Mont Sindoa) are particularly interesting. They include not only a suite of species typical of forests on ultramafic soils but also some taxa usually associated with forests on soil types typical of the central and northern ranges. This is, perhaps, not surprising, as these two peaks lie at the extreme northern edge of the large southern ultramafic block that occupies the southern third of New Caledonia (Paris, 1981; Sautter, 1981). Among species in the latter group is a distinctive new species of Nannoscincus that is most similar in appearance to Nannoscincus gracilis. This new species of Nannoscincus is the largest member of the genus and differs from all other members of the genus in having seven, rather than six, upper labial scales.

\section{Materials and methods}

Abbreviations. Specimen abbreviations are prefixed as follows: Auckland Museum (AIM); Australian Museum, Sydney (AMS); California Academy of Sciences, San Francisco (CAS); Museum of Comparative Zoology, Harvard (MCZ); Muséum national d'Histoire naturelle, Paris (MNHN).

The full suite of morphological characters listed below were scored for each specimen where possible.

Measurements. The following characters were scored: snout to vent length (SVL) - measured from tip of snout to caudal edge of anal scales; axilla to groin distancemeasured from middle of base of forelimb to middle of base of hindlimb; forelimb to snout length-measured from tip of snout to middle of base of forelimb; hindlimb lengthmeasured from middle of base of hindlimb to tip of fourth toe including nail; tail length-unless otherwise stated is measured from caudal edge of anal scales to tip of tail, on complete original tails only as determined radiographs. Body measurements are expressed as percentages of snout to vent length in the taxon accounts.

Scalation. Head scalation generally follows Taylor (1935) as described and figured by Sadlier (1986) and also includes: pre-temporals-enlarged scales following on from supraciliary series and positioned along lateral edge upper secondary temporal and upper anterior edge of primary temporal; post-ocular scales - enlarged scales following on from pre-temporal series along edge of lower eyelid and bordering lower anterior edge of primary temporal and upper edge of penultimate upper labial; post-temporals- number of scales positioned posterior to lower secondary temporal and ear opening; midbody scale rows-number of longitudinal scale rows around body counted midway between axilla and groin; paravertebral scales-number of scales in a row down the body from first scale posterior of parietal scale to last scale at level of vent opening; fourth finger and toe scales-number of dorsal scales on fourth digit of hand and foot, distal scale contains claw; basal scale of fourth finger is usually present as a single large scale common to the base of the fourth, third, and second finger; basal scale of fourth toe broadly contacts basal scale of adjacent third toe; fourth finger and toe lamellae-number of ventral scales on fourth digit of hand and foot, distal scale contains claw and basal scale is last largely undivided scale at a point level with intersection of third and fourth digits. Bilateral scalation characters were scored on both sides and the mean value used.

Osteology. Radiographs were prepared using a Eresco AS2 X-ray machine to determine phalangeal formulae and the number of presacral vertebrae and postsacral vertebrae (complete original tails only), at exposures of $30 \mathrm{sec}$ at $30 \mathrm{kV}$.

\section{Species account}

The genus Nannoscincus has been identified as a member of the Australasian Eugongylus group of lygosomine skinks (Greer, 1979). It is distinguished from other genera in the group by a combination of morphological synapomorphies that includes: fusion of the atlantal arches and intercentrum of the first cervical vertebra into a single element; an elongate body with 29 or more presacral vertebrae; phalanges of digits of the forelimbs reduced, with a phalangeal formula of 2.3.4.4.3 or less for the manus (Sadlier, 1990; Bauer \& Sadlier, 2000).

The Australian species, Siaphos maccoyi Lucas \& Frost, 1894, has previously been considered congeneric with the New Caledonian species of Nannoscincus by virtue of its sharing a similar pattern of phalanx reduction (Sadlier, 1990). However, this pattern has also been found in the recently described Australian species Lampropholis elongata Greer, 1997 and clearly represents a case of independent evolution of this particular character state. This independent derivation calls into question the significance of this character as a unifying synapomorphy for maccoy $i$ and the New Caledonian Nannoscincus. Further, mitochondrial and nuclear DNA sequence data (S. Smith et al., unpublished data in preparation) are inconsistent with a close relationship between these taxa. We therefore remove the species maccoyi from Nannoscincus, which we regard as a strictly New Caledonian genus. The formal placement of the Australian species into a separate genus is required and will need additional research in a broad comparative context.

Wells \& Wellington (1984) provided a new generic name, Anepischetos, for maccoyi and a new species, A. sharmani (the latter as type species). Subsequently recognizing that the name was preoccupied (Anepischetos Smith, 1900; Lepidoptera), Wells \& Wellington (1985) proposed a replacement generic name, Anepischetosia, and added a new species, A. brindabellaensis to the genus. Both A. sharmani and $A$. brindabellaensis were subsequently (Shea \& Sadlier, 1999) referred to the synonymy of Nannoscincus maccoyi due to the inadequacy of the diagnoses for differentiating the three putative species. Anepischetosia has precedence 


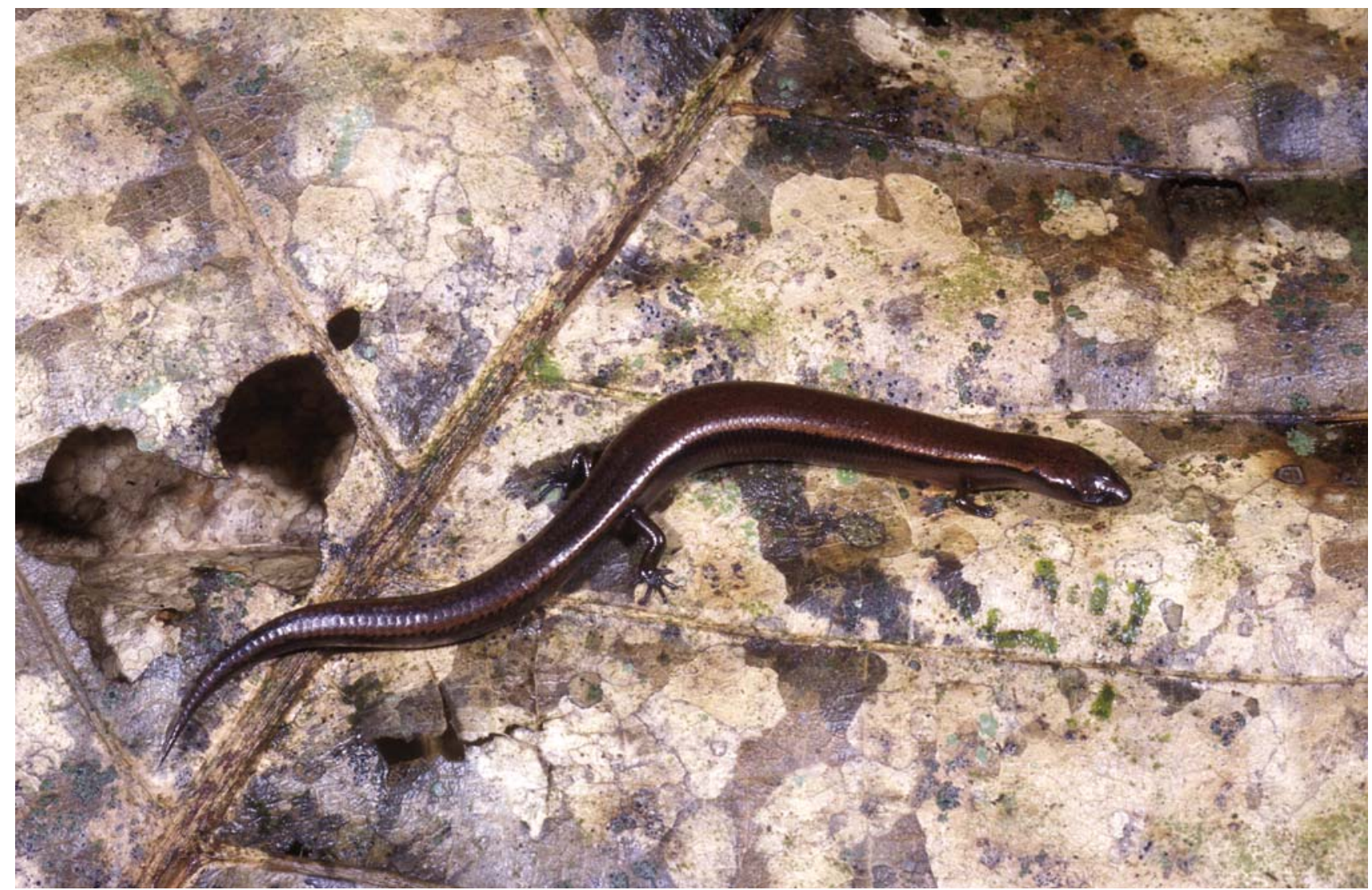

Fig. 1. Paratype of Nannoscincus garrulus n.sp. (AMS R163457).

over Nannoseps (type species Saiphos maccoyi) proposed by Sadlier (1990) as a subgenus of Nannoscincus, and hence we use the combination Anepischetosia maccoyi for the Australian species previously referred to Nannoscincus.

Within Nannoscincus two monophyletic species groups have been recognized on the basis of morphological data (Sadlier, 1990; Sadlier et al., 2002). One group contains the species $N$. mariei, $N$. rankini, $N$. greeri, $N$. hanchisteus, $N$. humectus, $N$. exos, and $N$. manaueti (a recently described species from the Massif de Kopéto), and the other group the species $N$. gracilis, $N$. slevini, and the species described here from Pic Ningua and Mont Çidoa. Although mitochondrial DNA sequence data are equivocal with respect to the monophyly of the first group, that of the latter is well supported (S. Smith et al., unpublished data). The species in this group are all superficially similar in that they have very elongate bodies and a markedly two-toned colour pattern. They also share a suite of distinctive apomorphic characters, two of which, a reduction in the number of phalanges of the third and fourth fingers to yield a phalangeal formula for the manus of 2.3.3.3.3 or less, and a highly elevated number of presacral vertebrae, are unique to this group within the context of all Nannoscincus.

\section{Nannoscincus garrulus n.sp.}

Figs 1-5

Type material. HoLOTYPE: MNHN 2003.1002 Pic Ningua, $17.0 \mathrm{~km}$ south of Nakaré, Province Sud, New Caledonia (21 $\left.{ }^{\circ} 44^{\prime} 25^{\prime \prime S ~} 166^{\circ} 09^{\prime} 21^{\prime \prime E}\right)$, collected by R.A. Sadlier, A.M. Bauer, T. Jackman, \& C.C. Austin on 27 September 2002. PARATYPES: AMS R163451-52, CAS 226164-65, MCZ
R183655 same collection data as holotype; AMS R16345357, CAS 226166-67 Pic Ningua, 17.0 km south of Nakaré, Province Sud, New Caledonia (2144'36"S 16609'02"E), collected by R.A. Sadlier, A.M. Bauer, T. Jackman, \& C.C. Austin on 26 September 2002.

Additional material. The following specimens referable to $N$. garrulus were collected in wet pit traps on both Pic Ningua and Mont Çidoa in 1993-1995, but do not form part of the type series: AMS R151490-97, R151499-511, R151513-17, R151520-26, R151528-34, R151536-46, AIM 1702, 1704, 1733, 1735-39, 1775-78, 1783-98, 1800$02,1815-18,1820-21$ from a range of sites $(n=7)$ between 970-1110 m elevation on Pic Ningua; AIM 1703, 1705, 1734, 1799, 1814, 1819 Mont Çidoa (21ํ4'S $\left.166^{\circ} 13 ' \mathrm{E}\right)$.

Diagnosis. Nannoscincus garrulus is a large and elongate member of the genus with a two-toned colour pattern on the body (Fig. 1). It can be distinguished from all other members of the genus by the following combination of characters: frontoparietals divided; two loreals, anterior loreal a small semilunar scale positioned off the posterodorsal edge of the enlarged nasal scale and failing to contact the labials; seven or more upper labial scales; left and right oviduct present in females; lower eyelid "scaled"; ear opening minute; body scales striated; adult dorsal colour two-toned; ear opening positioned four scales posterior to lower secondary temporal; presacral vertebrae 33-34; phalangeal formula for manus 2.3.3.3.3; phalangeal formula for pes 2.3.4.4.3.

The first four characters will distinguish $N$. garrulus from $N$. rankini, $N$. greeri, $N$. hanchisteus, $N$. humectus, $N$. exos, and $N$. manaueti, all of which have fused frontoparietals, a 

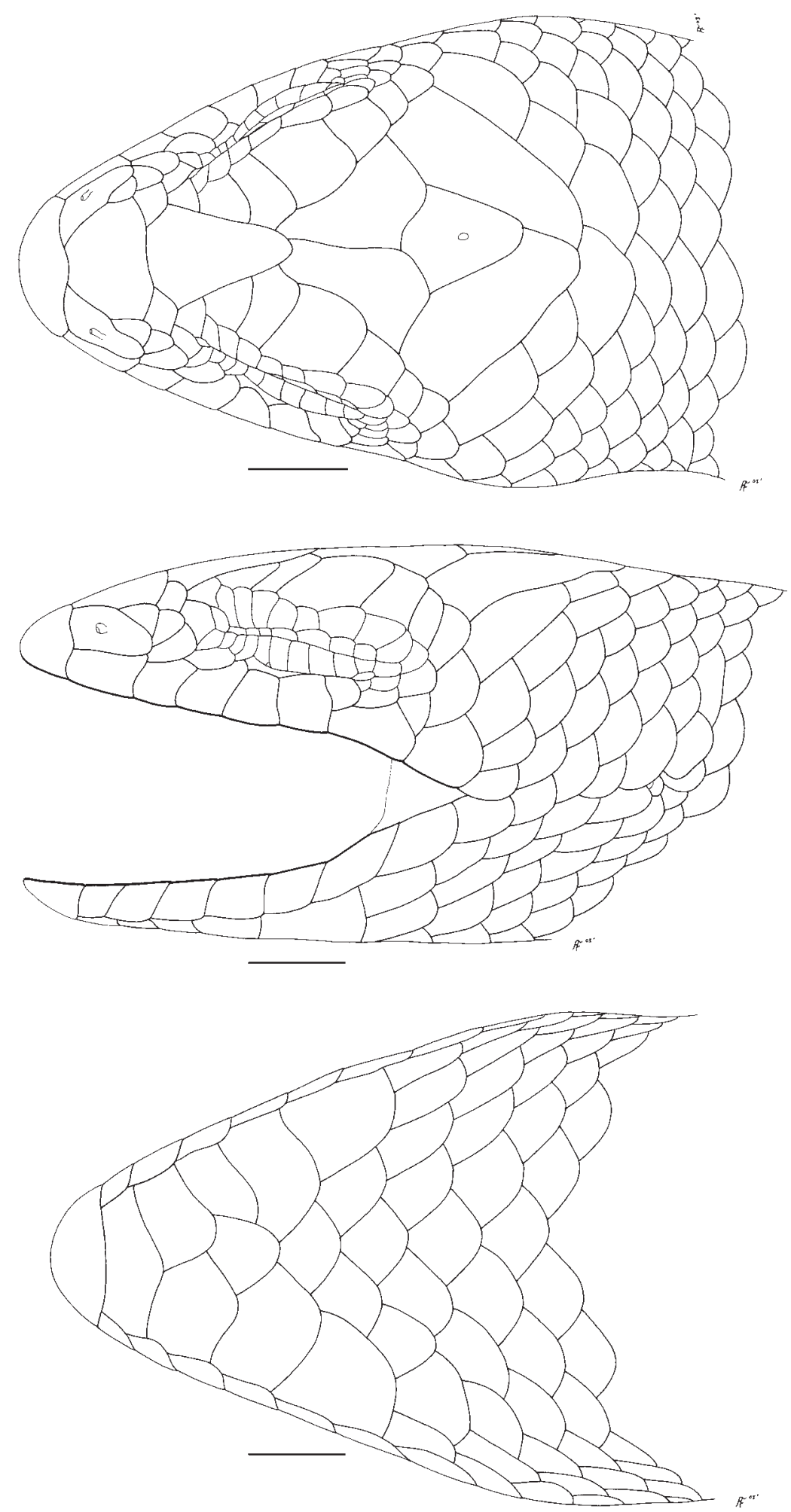

Fig. 2. Dorsal (upper), lateral (middle), and ventral (lower) views of the head of holotype of Nannoscincus garrulus n.sp. (MNHN 2003.1002) showing scalation.

single loreal, a windowed lower eyelid, and the oviduct present on the right side only. It can be further distinguished from these species by having fewer phalanges on the third and fourth fingers of the manus.

Nannoscincus mariei is somewhat intermediate between the two morphologically-defined species groups, in possessing the derived character state of a single loreal and loss of the left oviduct, but retaining the primitive character state of divided frontoparietals. It also has a "scaled" lower eyelid similar to $N$. gracilis, $N$. slevini, and $N$. garrulus, the structure and possible polarity of which has been discussed elsewhere (Sadlier, 1990). Nannoscincus garrulus is readily 


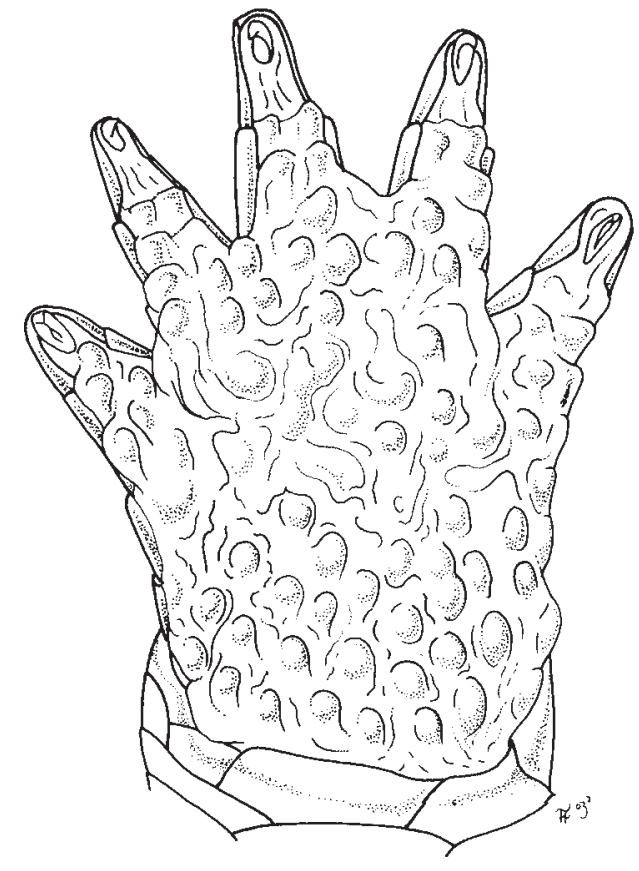

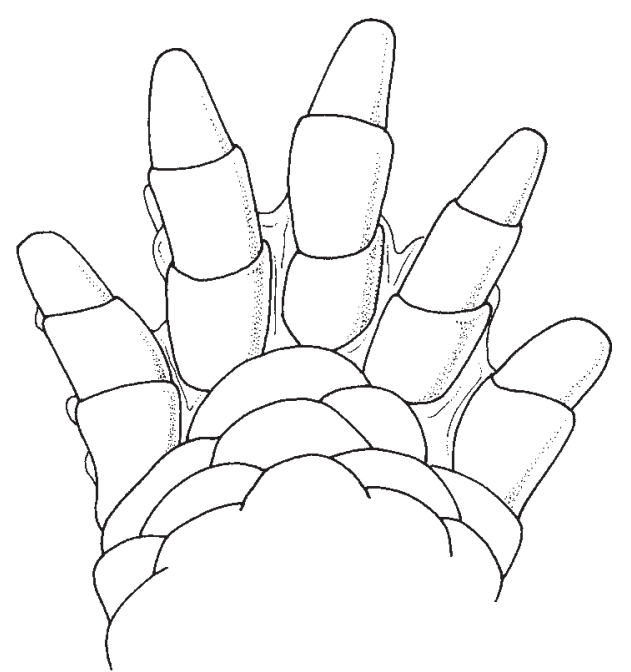

Fig. 3. Left manus of holotype of Nannoscincus garrulus n.sp. (MNHN 2003.1002) showing extensive underside "webbing" between digits of the forelimbs (right) and enlarged dorsal scales at the base of the third and fourth digits (left). distinguished from $N$. mariei by the presence of two ( $v s$ one) loreal scales, and the presence of a small but obvious ear opening ( $v s$ ear opening absent).

Nannoscincus garrulus most resembles $N$. gracilis and $N$. slevini. It is noticeably larger (maximum SVL $52.5 \mathrm{~mm}$ ) than either $N$. gracilis (SVL $49.0 \mathrm{~mm}$ ) or $N$. slevini (SVL $43.0 \mathrm{~mm}$ ), and has seven or more upper labial scales whereas both $N$. gracilis and $N$. slevini have six. It can be further distinguished

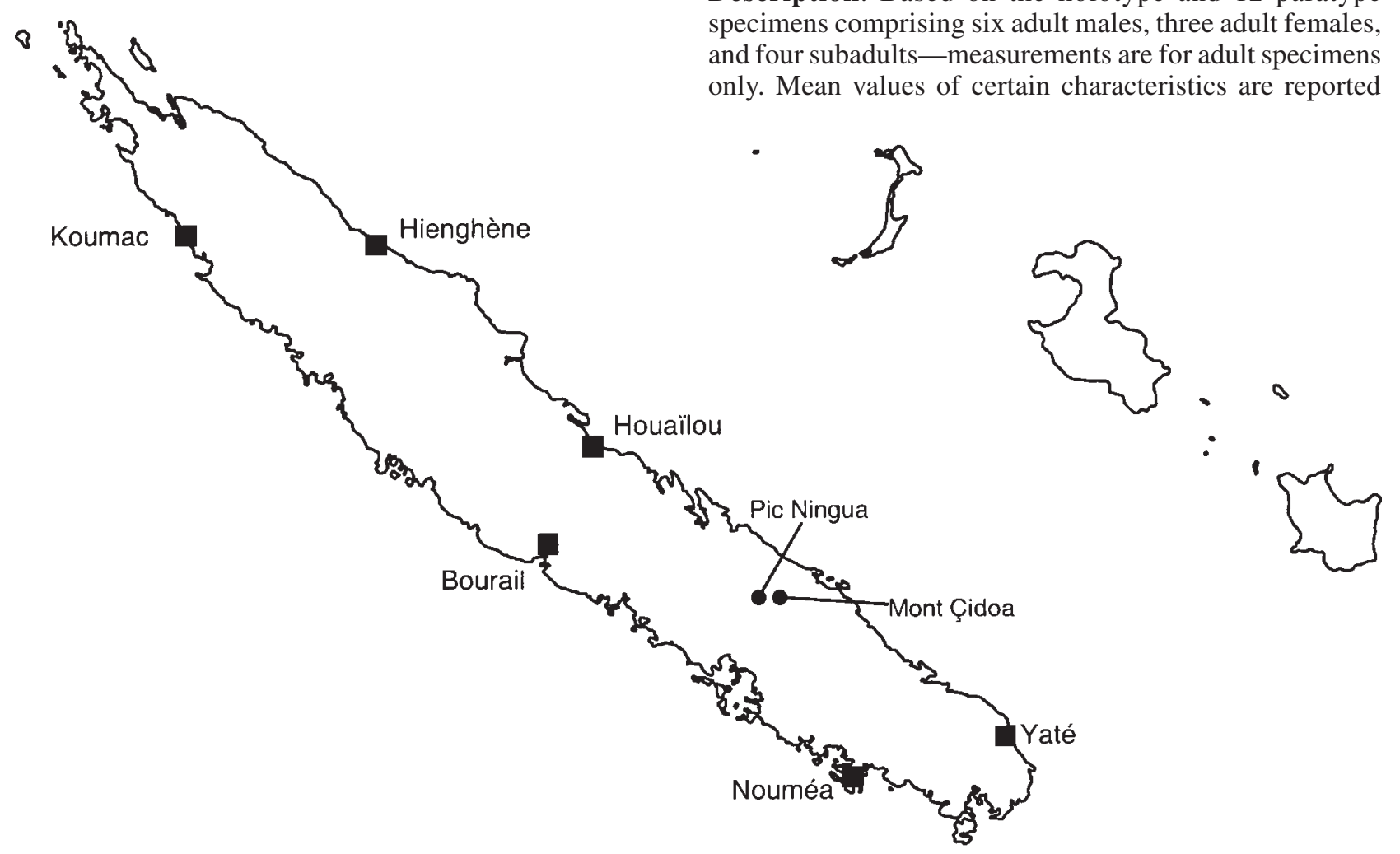

from $N$. slevini by the presence of five ( $v s$ four) digits on the manus, and from $N$. gracilis in having more phalanges on the fifth digit of the manus (2.3.3.3.3 vs 2.3.3.3.2).

Etymology. The specific epithet is the Latin word garrulus, meaning talkative, and is in reference to the tendency for this species to emit a squeaking sound when distressed (Bauer et al., 2004).

Description. Based on the holotype and 12 paratype specimens comprising six adult males, three adult females, and four subadults - measurements are for adult specimens only. Mean values of certain characteristics are reported

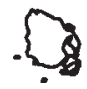

the only known locality for Nannoscincus garrulus n.sp. 


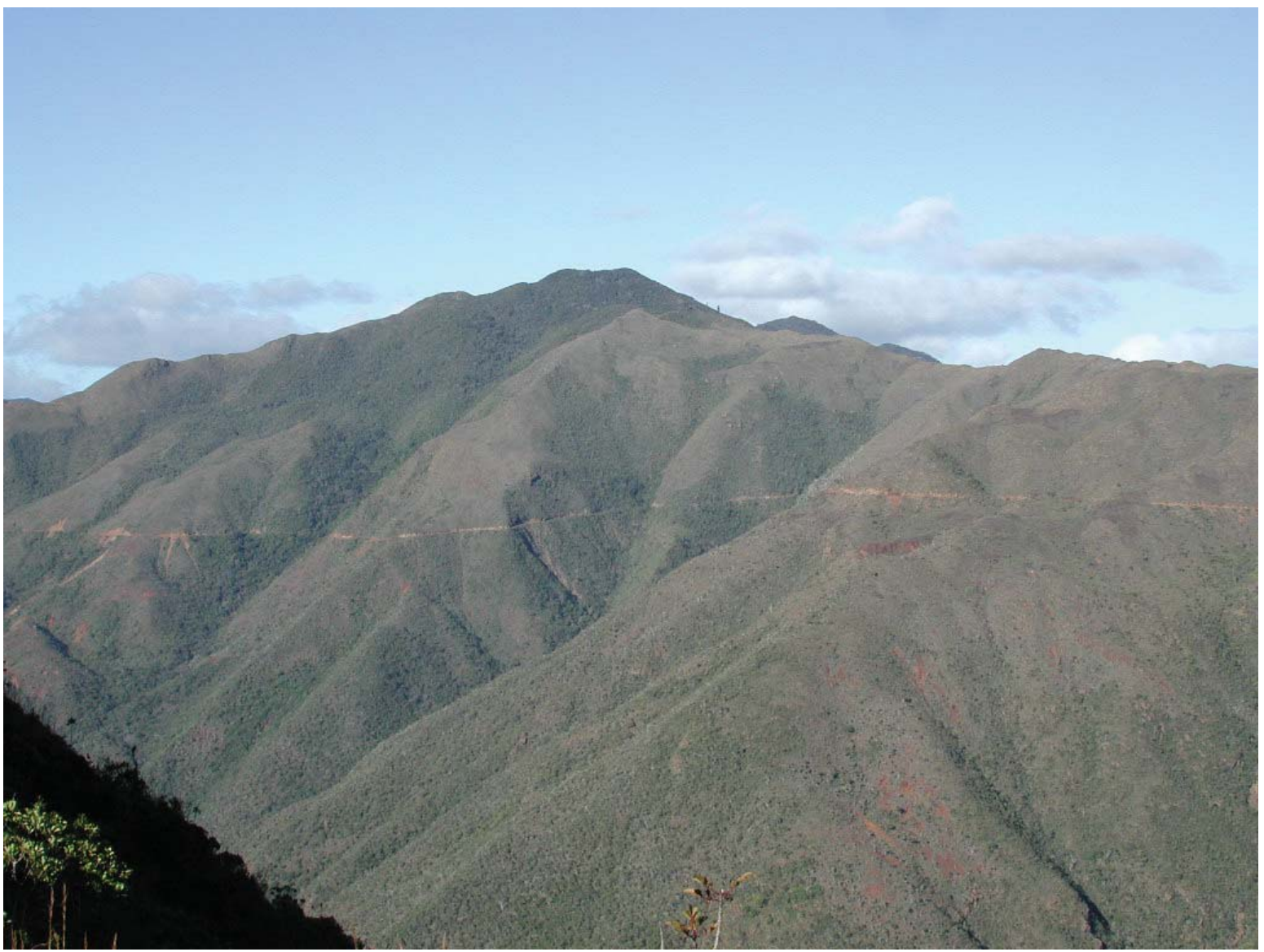

Fig. 5. Isolated closed forest patch on Mont Çidoa, typical of habitat in the area from which the types of Nannoscincus garrulus n.sp. were collected.

with standard deviations. Measurements: SVL 45.0-52.5 $\mathrm{mm}$; distance from axilla to groin $64.4-66.7 \%$ of SVL ( $\overline{\mathrm{x}}=$ $65.4)$; distance from forelimb to snout $28.6-31.3 \%$ of SVL $(\overline{\mathrm{x}}=29.9)$; hindlimb length $19.0-22.2 \%$ of SVL $(\overline{\mathrm{x}}=20.6)$; tail length $106.1 \%$ of SVL (estimated from individual with most complete tail). Scalation: Head (Fig. 2): nasals moderately separated, very large and extending laterally along the side of the head; frontonasal broader than long; prefrontals very small and widely separated; supraciliaries $7(81 \%)$, rarely 8 , with the first supraciliary contacting frontal (thereby excluding contact between the prefrontal and first supraocular); frontal short, almost as broad as long; supraoculars four; frontoparietals paired; interparietal distinct; parietals each usually bordered by a single nuchal and upper secondary temporal scale (73\%) but showing some fragmentation of scales in this region such that nuchals $(19 \%)$ or upper secondary temporals $(8 \%)$ are sometimes divided to form two scales; upper labials 7 (96\%), rarely 8 ; lower labials 7; two loreals, anterior loreal reduced to a small semilunar scale positioned off posterodorsal edge of enlarged nasal scale, posterior loreal also semilunar in shape, either contacting the labials narrowly $(42 \%)$ or excluded from contact by extension of posterior edge of large nasal back to contact lower preocular; single large anterior subocular; pretemporals two; postoculars $3(77 \%)$ or 4 ; primary temporal single $(46 \%)$, or divided to form two similar sized scales; upper secondary temporals usually single $(92.7 \%)$, occasionally divided to form two scales; lower secondary temporals single; tertiary temporals two; postlabials two; ear opening positioned four scales posterior to lower secondary temporal; postmental contacting first and second lower labial; chinshields three, first pair in broad contact. Body: scales striated, midbody scale rows 22-24 $(\overline{\mathrm{x}}=22.8 \pm 1.01)$; paravertebral scales $60-73(\overline{\mathrm{x}}=66.7 \pm 3.5)$. Limbs: scales on top of fourth finger $4-5(\overline{\mathrm{x}}=4.05 \pm 0.14)$; lamellae beneath fourth finger $4-5(\overline{\mathrm{x}}=4.1 \pm 0.30)$, rudimentary interdigital webbing at base of fingers (Fig. 3 ); scales on top of fourth toe 6-7 $(\overline{\mathrm{x}}=6.05 \pm 0.14)$, the basal scale present as a large scale at base of third and fourth toes; lamellae beneath fourth toe $13-16(\overline{\mathrm{x}}=13.77 \pm=0.83)$. Osteology: presacral vertebrae 33 or $34(54 \%, \mathrm{n}=13)$; postsacral vertebrae $37-38(n=2)$ phalangeal formula for manus and pes 2.3.3.3.3 and 2.3.4.4.3 $(\mathrm{n}=13)$, respectively.

Colouration (in preservative): dorsal colour light to mid brown, with scattered dark flecks aligned along vertebral axis to form a broken longitudinal line; nape with a variably defined pale blotch with a dark posterior edge. Lateral surface noticeably darker than dorsal, unmarked. Dorsal and lateral surfaces defined by a dark brown to black (darker than lateral colour) dorsolateral stripe, pale-edged above. Dark dorsolateral stripe extends from back of eye (inflected over tympanic region) to level of hindlimbs, breaking up and becoming poorly defined along tail. Head slightly darker at sides than adjacent areas of body, dark colouring extending around lower edge of rostral scale and inflecting upwards to form a dark midrostral streak in boldly marked individuals, subocular labials with pale markings. Ventral surface pale with a light to heavy concentration of scattered brown markings at edges and regular brown markings to throat region. 
Distribution and habitat. At present known only from Pic Ningua and Mont Çidoa, at the northern edge of the extensive ultramafic block that covers much of the southern third of New Caledonia (Fig. 4). Closed forest habitat (Fig. 5 ) is restricted to the top of these mountains from about $900 \mathrm{~m}$ elevation. All specimens were collected under logs and rocks in the vicinity of a small, shallow gully. The forest floor was generally dry at the time of collection, the island not having had significant rainfall since the previous wet season (January-March). The apparent absence of individuals away from the gully could indicate the species concentrates in areas where soil moisture is present, such as the gullies, during periods of seasonal dryness. Like all members of the genus, $N$. garrulus is highly desiccationprone (Bauer \& Sadlier, 2000).

The nearest records of the allied Nannoscincus gracilis are from mid elevation forest at Col de Nassirah (348 m) $10 \mathrm{~km}$ to the south and west, and Col de Petchécara (435 m) $15 \mathrm{~km}$ to the north and east, whereas $N$. slevini has been recorded from Mt Canala and Plateau de Dogny $25 \mathrm{~km}$ to the north and east.

Natural history. All specimens made faint but distinctive squeaks when handled, presumably as a defensive measure (Bauer et al., 2004). This is the only Nannoscincus, and only New Caledonian scincid, for which vocalization has been documented (under the name $N$. cf. gracilis-Bauer et al., 2004). One adult female collected in January, the summer wet season, contained two large yolked oviducal eggs (one in the left oviduct and one in the right), and another specimen two large yolked ovarian follicles.

Conservation status. Nannoscincus garrulus has an extremely restricted distribution, being known only from the type locality at Pic Ningua and adjacent Mont Çidoa. That it was not recorded from high elevation on forest on nearby Mt Do indicates the species is not necessarily likely to be more widely distributed. Closed forest habitat occurs at Bwa Bwi $(19 \mathrm{~km}$ ESE of Pic Ningua and $9 \mathrm{~km}$ SSE of Mont Çidoa) and possibly Dent de St-Vincent (20 km SSE of Pic Ningua), both of which lie along a more or less continuous high elevation ridge. However, neither site has yet been surveyed. The size of high elevation forest patches in this area of the southern ultramafic block is extremely small, especially on Pic Ningua and Mont Çidoa.

The forest on Pic Ningua has been set aside as a special reserve. An access road to the mining operation passes along one edge of the forest. Given the very steep relief of the terrain and the small size of the forest patches, any mining activity through or adjacent to the forest has the potential to alter a significant proportion of the overall area of the forest. The mid slopes of the ranges in this part of the island are covered with maquis, and there is a very narrow transition zone between this and the high elevation closed forest. Frequent burning of maquis shrubland, particularly in areas near settlement or development, and its impact upon the forest edge is considered a significant threat to the overall size and quality of isolated closed forest patches in New Caledonia (Fig. 5).
Given the species' highly restricted distribution, the relatively small size of the remaining moist forest on Pic Ningua and Mont Çidoa, and the threat to this habitat from fire, the species would be ranked as Endangered under a modified IUCN classification system (Sadlier \& Bauer, 2003) where area of occupancy $<100 \mathrm{~km}^{2}$, number of populations $=2$, and there is an apparent continuing decline in area, extent and/or quality of habitat.

Relationships. A previous scheme of relationships for Nannoscincus (Sadlier, 1990) identified two groups, the $N$. gracilis group comprising $N$. gracilis $+N$. slevini, and the $N$. mariei group comprising the species $N$. mariei $+N$. rankini $+N$. greeri. The species $N$. hanchisteus, $N$. humectus, and $N$. exos were subsequently added to the latter group (Sadlier et al., 2002), and later N. manaueti (Sadlier et al., 2004).

The $N$. mariei group is a well diagnosed clade, characterized by loss of the left oviduct in females, loss of the anterior loreal scale, and a reduced number of lower labial scales. The $N$. gracilis group also constitutes a clade characterized by a reduction in the number of phalanges in the third and fourth digits of the manus, a pattern of scale reduction in the loreal region resulting in both the anterior and posterior loreals being reduced to small semilunar scales, and a tendency towards greater elongation of the body as seen in the greatly increased number of presacral vertebrae.

Nannoscincus garrulus is clearly a member of the $N$. gracilis group. It is also very distinct from either $N$. gracilis or $N$. slevini in having a number of unusual scalation characteristics including: fragmentation in the region of the primary temporal such that two scales rather than one are often present; fragmentation in the region of the nuchal such that two or more scales rather than one are sometimes present; an increased number of post temporal scales such that four, rather than three or fewer, scales occur between the lower secondary temporal and the ear opening; a tendency for displacement of the posterior loreal by contact between the lower preocular and nasal to exclude contact between the posterior loreal and upper labial scales on occasions; an increased number of lower labial scales such that seven scales border the lip between the mental scale and angle of the jaw; and the presence of seven upper labial scales with three rather than two labial scales positioned below the eye in the area between the anterior preocular scale and postsubocular scales (the fourth wholly bordering the lower eyelid, the third and fifth partially). It is likely that the condition seen in $N$. garrulus for the first three of these characters is apomorphic. The polarity of the upper labial scale character in $N$. garrulus is, however, less clear. All other species of Nannoscincus tend to have only two scales (more or less similar in size) positioned immediately below and wholly or partially bordering the lower eyelid. It is possible the extra upper labial bordering the lower eyelid of $N$. garrulus is derived from a division of one of the two upper labial scales usually seen in other species of Nannoscincus that are positioned immediately below and bordering the lower eyelid. 
ACKNOWLEDGMENTS. The authors thank the New Caledonian authorities for permission to collect and conduct research in Province Sud, particularly M. Richard Farman. The types of Nannoscincus garrulus were collected during field research funded by grant DEB 0108108 from the National Science Foundation (U.S.A.), and the specimens were collected under permit 6034-2075/DRN issued by the Direction des Ressources Naturelles of the Province Sud, New Caledonia and exported under permit 6034-2330/DRN of the same authority. The authorities at Société le Nickel (SLN) kindly allowed access to Pic Ningua. Unfailing logistical support and encouragement was provided by Jean Chazeau of the IRD Centre de Nouméa. Hannah Finlay produced the illustration of the head shields (Fig. 2). Todd Jackman and Christopher Austin assisted with fieldwork.

\section{References}

Bauer, A.M., T. Jackman, S.A. Smith, R.A Sadlier \& C.C. Austin, 2004. Natural history note. Nannoscincus gracilis. Vocalization. Herpetological Review 35: 268-269.

Bauer, A.M., J.P.G. Jones \& R.A. Sadlier, 2000. A new highelevation Bavayia (Reptilia: Diplodactylidae) from northeastern New Caledonia. Pacific Science 54: 63-69.

Bauer, A.M., \& R.A. Sadlier, 2000. The Herpetofauna of New Caledonia. Ithaca, NY: Society for the Study of Amphibians and Reptiles.

Greer, A.E., 1979. A phylogenetic subdivision of Australian skinks. Records of the Australian Museum 32(8): 339-371.

Paris, J.P., 1981. Géologie de la Nouvelle-Calédonie. Mém. B.R.G.M. 113. 278 pp., 2 separate maps.

Sadlier, R.A., 1986. A review of the scincid lizards of New Caledonia. Records of the Australian Museum 39(1): 1-66.

Sadlier, R.A., 1990. The scincid lizard genus Nannoscincus Günther: a revaluation. Memoirs of the Queensland Museum 29: 487-494.

Sadlier, R.A., \& A.M. Bauer, 1999. The scincid lizard genus Sigaloseps (Reptilia: Scincidae) from New Caledonia in the southwest Pacific: description of a new species and review of the biology, distribution, and morphology of Sigaloseps deplanchei (Bavay). Records of the Australian Museum 51(1): 83-91. http://www.amonline.net.au/pdf/publications/1296_complete.pdf

Sadlier, R.A., \& A.M. Bauer, 2000. The Sadlier R.A. \& Bauer A.M., 2000. The scincid lizard genus Marmorosphax (Reptilia: Scincidae) from New Caledonia in the southwest Pacific: description of a New species Restricted to High-Altitude Forest in Province Sud. Pacific Science 54(1): 56-62.

Sadlier, R.A., \& A.M. Bauer, 2003. Conservation status of endemic New Caledonian lizards - an assessment of the distribution and threats to the species of lizard endemic to New Caledonia.

http://www.amonline.net.au/herpetology/research/lizards_conservation_intro.htm

Sadlier, R.A., A.M. Bauer \& A.H. Whitaker, 2002. The scincid lizard genus Nannoscincus Günther from New Caledonia in the southwest Pacific: a review of the morphology and distribution of species in the Nannoscincus mariei species group, including the description of three new species from the Province Nord. Zoologica Neocaledonia 5, Mémoires du Muséum national d'Histoire naturelle 187: 269-276.

Sadlier, R.A., A.M. Bauer, A.H. Whitaker \& S.A. Smith, 2004. Two new species of lizards (Squamata) from the Massif de Kopéto, New Caledonia. Proceedings of the California Academy of Sciences 55(11): 208-221.

Sautter, G., coord., 1981. Atlas de la Nouvelle Calédonie et Dépendances. Paris: O.R.S.T.O.M. 118 pp, 53 maps, 1 acetate overlay map.

Shea, G.M., \& R.A. Sadlier, 1999. A catalogue of the non-fossil amphibian and reptile type specimens in the collection of the Australian Museum: types currently, previously and purportedly present. Technical Reports of the Australian Museum 15: 1-91. http://www.amonline.net.au/pdt/publications/1290_complete.pdf

Taylor, E.H., 1935. A taxonomic study of the cosmopolitan scincoid lizards of the genus Eumeces with an account of the distribution and relationships of its species. Science Bulletin of the University of Kansas 36(14): 642 pp.

Wells, R.W., \& C.R. Wellington, 1984. A synopsis of the class Reptilia in Australia. Australian Journal of Herpetology 1(34): 73-129.

Wells, R.W., \& C.R. Wellington, 1985. A classification of the Amphibia and Reptilia of Australia. Australian Journal of Herpetology Supplementary Series 1: 1-61.

Manuscript submitted 30 January 2004, revised 10 May 2005 and accepted 30 June 2005.

Associate Editor: Sandy Ingleby. 